\title{
0 de lá e o de cá: apontamentos para uma categorização do conteúdo das emissoras comerciais brasileiras com base na influência do rádio dos Estados Unidos
}

////////////////// : Luiz Artur Ferraretto ${ }^{1}$

1. Doutor em comunicação e informação pela Universidade Federal do Rio Grande do Sul, mesma instituição onde atua como professor no curso de comunicação social - jornalismo. Coordenador do Grupo de Pesquisa em Rádio e Mídia Sonora da Sociedade Brasileira de Estudos Interdisciplinares da Comunicação (2007-2010). Autor dos livros Rádio: o veículo, a história e a técnica, Rádio no Rio Grande do Sul (anos 20, 30 e 40) e Rádio e capitalismo no Rio Grande do Sul: as emissoras comerciais e suas estratégias de programação na segunda metade do século 20. E-mail: luiz.ferraretto@ufrgs.br 


\section{Resumo}

Proposta de categorização do conteúdo radiofônico, considerando quatro níveis de planejamento: (1) o do segmento, (2) o do formato, (3) o da programação e (4) o do conteúdo em si, este último normalmente organizado na forma de programas. Tem por objetivo aproximar o que é praticado nas emissoras comerciais do Brasil dos processos adotados no rádio dos Estados Unidos, mercado tido como referencial para o empresariado nacional, e contrastá-los. Para tanto, parte de uma revisão bibliográfica a respeito, considerando obras de autores como Fornatale e Mills (1980), Warren (2005), Keith (2010) e Hausman, Messere, O’Donnell e Benoit (2010); e verbetes relacionados ao tema da The Museum of Broadcast Communications encyclopedia of radio, editada por Sterling (2004).

Palavras-chave

Rádio comercial, Brasil, Estados Unidos, conteúdo, categorização.

Abstract

A proposal of categorization of radiophony content, considering four levels of planning: (1) the segment, (2) the format, (3) the programming and (4) the content itself, this last one usually organized in the shape of programs. The objective is to approach and contrast what is practiced in the commercial radio broadcasting stations in Brazil to processes adopted by the radios in the United States, a market which is as a reference for the national entrepreneurship. For this, there will be part of a bibliographic review in relation to the subject, considering work of authors like Fornatale and Mills (1980), Warren (2005), Keith (2010) and Hausman, Messere, O'Donnell and Benoit (2010); and notes on the topic from The Museum of Broadcast Communications Encyclopedia of Radio, published by Sterling (2004).

Keywords Commercial radio, Brazil, United States of America, content, categorization. 
2. Como descrevo no artigo Aqui, o rádio de lá: uma análise histórica das influências estrangeiras nas emissoras brasileiras (2010).
O que define efetivamente uma emissora em sua relação com o público? Qualquer gestor competente da área de rádio vai responder a essa pergunta recorrendo a algum elemento que, em última análise, remete, por óbvio, ao conteúdo e/ou à forma como o rádio se apresenta para o ouvinte. E, não raro, terá por referencial o que acontece no mercado dos Estados Unidos. Tem sido, assim, historicamente ${ }^{2}$. Pensar esse processo - o de definição do conteúdo ofertado pelo rádio — , infelizmente, não resultou objeto de estudo frequente dentro das universidades brasileiras. Analisam-se emissoras, programas ou programações, mas, raramente, procuramos, nós, os pesquisadores, refletir sobre o planejamento e sobre a gestão de conteúdo como um todo. Sobram críticas, mas faltam, muitas vezes, creio, explicações sobre o como fazer. Aqui, portanto, procuro, à luz da bibliografia estadunidense, oferecer algumas pistas com a intenção de suscitar outras reflexões. Da ignorância em relação às metodologias de planejamento de conteúdo - de formatação das emissoras, talvez dissessem os norte-americanos - ressentem-se a academia e, com certeza, pela falta de análises mais abrangentes que o auxiliem, o mercado brasileiro de rádio.

Nestes apontamentos, sigo a linha de raciocínio de Eduardo Meditsch (2002, p. 58-9), segundo a qual a pura e simples importação de modelos desenvolvidos nos Estados Unidos, sem adaptações, não teria chances de vingar em outro tipo de realidade socioeconômica como a brasileira. Acrescento ao constatado pelo professor da Universidade Federal de Santa Catarina que os 
radiodifusores daqui foram pródigos em importar tais modelos prontos e adaptá-los. De fato, creio, não se desenvolveu a prática metodológica que leva à consecução plena do processo de conformação de conteúdo nos moldes estadunidenses, com o planejamento baseado em pesquisa sendo substituído com frequência por impressões e intuições de gestores.

Com relação às emissoras brasileiras, em termos de estudos mais abrangentes no sentido de categorizar o que é veiculado, as exceções são os trabalhos de André Barbosa Filho (2003) e Janine Marques Passini Lucht (2010). São válidas obviamente, embora o aqui encetado difira consideravelmente delas, já que me baseio, de modo preponderante, nas concepções correntes no mercado dos Estados Unidos, em especial nas relacionadas ao conceito de formato de programa ou de programação, chave, no meu entender, para a compreensão dessas diferenças.

Para pensar conceitualmente o rádio de lá, parto de uma revisão bibliográfica das obras de Fornatale e Mills (1980), Warren (2005), Hausman, Messere, O’Donnell e Benoit (2010) e Keith (2010). Considero também verbetes relacionados ao tema incluídos na The Museum of Broadcast Communications encyclopedia of radio (STERLING, 2004), sem dúvida a mais abrangente obra em língua inglesa relacionada ao rádio. Procuro, desse modo, enquadrar em suas proposições o rádio comercial brasileiro. Aqui talvez falte um trabalho mais sistemático próprio de uma pesquisa de campo, que, por óbvio, se encontra além dos limites deste breve ensaio, tomado na expressão de seu título como um conjunto de apontamentos iniciais. Dou continuidade, ainda, a reflexões anteriores - Aqui, o rádio de lá: uma análise histórica das influências estrangeiras nas emissoras brasileiras (2010); e Uma proposta de periodização para a história do rádio no Brasil (2012) - , com base nas quais procuro atualizar categorizações apresentadas em Rádio: o veículo, a história e a técnica (2007).

A ideia básica - de conhecimento de qualquer gestor mediano - é que a programação de uma emissora deve relacionar dois processos, os quais envolvem anseios, interesses, necessidades e/ ou objetivos: (1) o de quem produz o conteúdo e (2) o de quem 
3. Uma rádio musical, por exemplo, pode ter programação - uma sequência de canções intercaladas pela participação de um comunicador, sem que elas se encontrem agrupadas formalmente em programas. o recebe. Essa articulação, longe de ser algo instintivo ou simples, engloba, necessariamente, uma reflexão apurada, um planejamento exaustivo e um acompanhamento constante. Trata-se de pensar uma identidade para o emissor e uma estratégia para que ela se reflita na mensagem destinada ao ouvinte, razão de ser do rádio. É uma necessidade premente que ganha mais importância a partir da atual e enorme disponibilidade de conteúdos - jornalísticos, de serviço, de entretenimento, musicais, educativos, publicitários... - nos mais diversos suportes - folhetos, jornais, revistas, estações de televisão, sites, blogs, arquivos para download ou streaming... - , com os quais o rádio tem de disputar a atenção do público. Essa perspectiva, que engloba aspectos conceituais e metodológicos, perpassa, além da ideia de identidade, quatro níveis estratégicos: (1) o do segmento, (2) o do formato, (3) o da programação, e (4) o dos conteúdos em si, normalmente manifestados na forma de programas ${ }^{3}$.

\section{A construção da identidade}

Associado a ideias como "fazer saber, tornar comum, participar" (FERREIRA, 1983, p. 386), o ato de comunicar remete também à empatia, que pode ser compreendida com base em concepções: (1) gerais - "faculdade de compreender emocionalmente um objeto", "capacidade de projetar a personalidade de alguém num objeto, de forma que este pareça como que impregnado dela" e "capacidade de se identificar com outra pessoa, de sentir o que ela sente, de querer o que ela quer, de apreender do modo como ela apreende etc.", (2) psicológicas - "processo de identificação em que o indivíduo se coloca no lugar do outro e, com base em suas próprias suposições ou impressões, tenta compreender o comportamento do outro"; e (3) sociológicas - "forma de cognição do eu social mediante três aptidões: para se ver do ponto de vista de outrem, para ver os outros do ponto de vista de outrem ou para ver os outros do ponto de vista deles mesmos" (HOUAISS, 2007).

O rádio, em qualquer de suas manifestações comunicacionais, objetiva criar uma relação de empatia com o público. É algo que envolve sentimentos de pertença, da atribuição do papel de 
companheiro virtual à emissora à noção de que aquela estação representa os anseios, os interesses, as necessidades e/ou os objetivos de cada ouvinte. Baseia-se na compreensão do que aquela manifestação radiofônica significa, projetando ali uma espécie de personalidade ou respondendo àquela construída pelo emissor e criando, assim, uma identificação. Dos pontos de vista psicológico e sociológico, a construção da empatia envolve o ouvinte, colocando-o dentro, no plano do imaginário, da narrativa; simulando um diálogo; oferecendo-lhe o que, em tese, ele deseja escutar. Esse processo inclui uma série de aspectos sintetizados na ideia despertada no receptor a respeito do conjunto de mensagens e de seu emissor. Obriga, assim, ao desenvolvimento de uma identidade clara, talvez o aspecto mais importante a ser considerado nesse processo:

\footnotetext{
Não importa qual o formato, que tipo de música toca, qual a cidade onde está localizada ou quantos concorrentes possui, a única coisa que é absolutamente necessária ao sucesso como negócio de uma rádio é definir uma identidade para ela. A identidade de uma emissora precisa ser uma combinação de tudo que a rádio representa para os seus ouvintes, sintetizada em um ou dois elementos altamente identificáveis. Uma identidade é a única coisa que, quando as pessoas veem, ouvem ou pensam no nome da emissora, proporciona essencialmente uma imagem instantânea da própria rádio. A identidade da emissora pode ser obtida principalmente por meio do que é oferecido aos ouvintes em termos de programação (WARREN, 2005, p. 97).
}

Em seu Radio: the book, uma publicação sob a chancela da NAB (National Association of Broadcasters), entidade representativa dos empresários do setor nos Estados Unidos, Steve Warren define, desse modo, o que a noção de identidade representa para uma emissora comercial. Conforme Warren (2005, p. 97), a eficácia da identidade está associada à consistência de mensagem em si, de estilos e formas de apresentação e locução, das palavras de ordem e slogans empregados, enfim, de um conjunto ajustado de elementos que perpassa todas as atividades o tempo todo e é facilmente reconhecido pelo público. É um processo relacionado à ideia de 
marca e ao que os profissionais de marketing chamam de branding. A respeito define Jean-Charles Jacques Zozzoli (2010, p. 783):

\begin{abstract}
Além de ser, e por ser, um elemento identificador e diferenciador, preferencialmente legível, audível, facilmente pronunciável e memoriável, evocador e declinável, a marca é um patrimônio. Constitui-se como contrato entre seu titular e seus públicos.

Nessa perspectiva, o anglicismo branding é comumente utilizado para designar o conjunto de atividades que visa à construção e ao fortalecimento de uma marca, isto é, a política de marca e o poder dessa marca no mercado e na sociedade, numa preocupação com seu valor [...].
\end{abstract}

4. Entrevista concedida por correio eletrônico, em 21 de maio de 2011, a Ayrton Mandarino, gerente da emissora no momento da reformulação. Cópia fornecida pelo entrevistado ao autor.
Zozzoli (2010, p. 783-4), usando como referência David Aaker, acrescenta a respeito do conceito de brand equity ou capital de marca proposto pelo estadunidense: "Essa denominação [...] remete aos ativos e passivos agrupados em relação à lealdade à marca, ao conhecimento do nome, à qualidade percebida, às associações à marca em acréscimo à qualidade percebida; a outros ativos do proprietário da marca". Nesse contexto, para ficar claro como se pode construir a identidade de uma emissora e como ela se relaciona com a marca e com o processo de branding, toma-se como exemplo o projeto desenvolvido, de agosto de 2008 a maio de 2009, pela Tecnopop, empresa de consultoria, para a Rádio Globo, com repercussões nas afiliadas da rede liderada pela emissora controlada pela família Marinho. Integraram a equipe responsável pelo projeto: André Stolarski, na direção e design; Theo Carvalho, design, desenvolvendo o novo sistema de identidade visual; e Fernando Morgado, que, além de dar assistência aos demais, atuou no branding em si com a pesquisa - iconográfica, histórica, mercadológica, de campo etc. - , no desenvolvimento da plataforma de marca a ser implantada na emissora - essência, valores, posicionamento etc. - e criando alternativas para aplicação prática na programação. Conforme Morgado ${ }^{4}$, o trabalho realizado procurou "posicionar a Rádio Globo como uma marca de conteúdo de áudio voltado ao jornalismo, esporte e talk, focado nas classes B e C, que atue de forma independente da banda ou tecnologia empregada para 
transmissão desse conteúdo", tornando-a "ainda mais atraente aos anunciantes e ouvintes - especialmente aqueles com idade entre 35 e 50 anos". Com base no posicionamento histórico da Globo como uma rádio popular de intensa simulação de conversa com o ouvinte, a consultoria identificou o perfil existente então:

O destaque que a emissora dá ao jornalismo e à prestação de serviço é um ponto importante, mas não se trata aqui da notícia que pode ser encontrada em qualquer outra emissora, site ou jornal: na Rádio Globo, a informação é contextualizada, interpretada e traduzida por profissionais que são mais do que comunicadores: são amigos dos seus ouvintes e que, por isso, desfrutam de uma credibilidade e uma presença que só mesmo os amigos de verdade possuem.

Mas a Rádio Globo não está só nos momentos sérios; ela está na emoção dos estádios e no humor que permeia vários programas. A capacidade de combinar seriedade e descontração, nas doses e horas certas, é outra característica que só os amigos de verdade possuem.

Se, dentro da história do rádio brasileiro, a Rádio Nacional pode ser vista como o símbolo máximo da fase dos programas de auditório e das radionovelas, a Rádio Globo é a protagonista e uma das precursoras da era do comunicador-amigo, ou seja, aquele que fala o que realmente interessa ao seu ouvinte com a máxima intimidade e coloquialidade, sem jamais perder o respeito e o seu compromisso com a boa comunicação. (TECNOPOP, 2009b).

Para levantar esses dados, além da análise de mercado e da concorrência, foram realizadas entrevistas com comunicadores, gestores, produtores e, em especial, ouvintes da emissora. Uma ideia, então, surgiu como central - amizade —, sendo desdobrada em oito valores, "que se encaixam perfeitamente no dia-a-dia de todas as atividades desenvolvidas pela Rádio Globo tanto com os seus ouvintes quanto com anunciantes, funcionários e afiliadas: proximidade, intimidade, respeito, compromisso, diversão, conciliação, credibilidade e lealdade" (TECNOPOP, 2009b). Dentro dessa proposta, um novo slogan, desenvolvido a partir de sugestões do publicitário Luiz Vieira, passou a ser adotado: 


\begin{abstract}
"Bota amizade nisso!". Essa expressão, que já está na boca do povo, é um reconhecimento de que a relação da rádio com seus ouvintes já é muito mais que uma simples simpatia: é um incentivo para que tudo seja feito com o espírito da amizade. Notícias, esporte, serviços, variedades, opinião? Bota amizade nisso! Negócios, espírito de equipe, relação com as emissoras amigas? Bota amizade nisso! Esse é o espírito da Rádio Globo, e só a Rádio Globo tem esse espírito (TECNOPOP, 2009c).
\end{abstract}

Em termos de rede, foi abandonada a identificação Rádio Globo Brasil, abrindo espaço para a associação da emissora amiga expressão que passou a substituir a "antiga e fria denominação afiliadas" (TECNOPOP, 2009c) - ao nome da cidade onde ela tem a unidade, tudo pensado no sentido de aumentar a noção de proximidade com o ouvinte. Nos anúncios em outros meios e nas ruas, a Rádio Globo ganhou também uma nova identidade visual.

Creio que esse exemplo permite compreender bem a definição - ou, no caso específico, de redefinição - da identidade de uma emissora. Como já ressaltado, tal processo aparece imbricado com os que refletem a respeito de segmento, formato, programação e conteúdo si.

\title{
O segmento
}

É comum, parece-me, no rádio brasileiro, a confusão entre formato, nível estratégico de planejamento em rádio que vai ser abordado mais adiante, e a ideia de segmento. Peter Fornatale e Joshua Mills (1980, p. 61) delimitam bem essa diferença ao afirmarem que o objetivo de um formato "é permitir às emissoras de rádio o fornecimento aos anunciantes de um grupo de consumidores mensurado e definido, conhecido como segmento". A delimitação do segmento, portanto, precede a do formato. Em realidade, pode-se trabalhar dentro de um mesmo segmento com um formato determinado concorrendo com outros gerados por abordagens diversas. Observa-se, no entanto, que todos esses níveis estratégicos de planejamento imbricam-se e sobrepõem-se constantemente na construção da identidade. 
Do momento em que, no rádio, passou a preponderar o negócio até a ascensão da TV como principal meio massivo, a maioria das emissoras buscou atingir públicos amplos com uma programação baseada em uma média de gosto generalizante. Embora o mercado já tivesse registrado algumas experiências anteriores de segmentação, é na segunda metade da década de 1980 que essa prática difunde-se. Como ensina Raimar Richers (1989, p. 14), que não faz menção ao rádio especificamente, mas sim à atividade econômica como um todo, a segmentação representa um critério diferente de abordagem, considerando a heterogeneidade do público, o que justifica, assim, a concentração de um esforço de marketing em uma dada fatia do mercado.

O processo de concentração de uma rádio em um dado segmento pode englobar apenas alguns programas ou a totalidade das transmissões. Significa oferecer um serviço com destinatário definido, buscando também anunciantes adequados a esses ouvintes específicos. Alguns critérios vão referenciar o corte feito na audiência total para ir ao encontro de um público-alvo. Em centros de grande e médio porte, levam-se em consideração, de modo genérico, aspectos (1) geográficos, (2) demográficos e (3) socioeconômicos, ou seja, particularidades em relação aos seus ouvintes em potencial, como idade, sexo, local de domicílio, classe de renda, instrução, ocupação, status, mobilidade social... A esses fatores somam-se possibilidades oferecidas por outras opções de segmentação citadas por Richers (1991, p. 19-21), que se baseiam em dados mais específicos do público-alvo e que, necessariamente, devem ser coletados com base em pesquisa. Tais modalidades aplicam-se, conforme o economista, "primordialmente a serviços e, sobretudo, a bens de consumo" (RICHERS, 1991, p. 21). São elas, aqui já adaptadas ao meio rádio, evidentemente um serviço, as formas de segmentação por (1) padrões de consumo, o que o ouvinte compra e com que frequência; (2) benefícios procurados, o que de gratificações ou de utilidades determinado conteúdo oferece à sua audiência; (3) estilos de vida, parâmetros comportamentais identificados no modo como as pessoas ocupam o tempo, encaram o contexto em que vivem ou gastam dinheiro; e (4) tipo de personalidade, a suscetibilidade, por exemplo, à influência de líderes de opinião. 
Resumindo, portanto, define-se segmentação como um processo em que, a partir da conciliação entre os anseios, interesses, necessidades e/ou objetivos do emissor e do receptor, além da identidade construída pelo primeiro, foca-se o rádio em uma dada parcela do público. Obviamente, ao ir das características mais genéricas para as mais específicas, agrupando ouvintes por suas particularidades na conformação da audiência pretendida, vai se definindo uma abordagem inicial e mais genérica do conteúdo. O segmento, portanto, é o resultado desse processo, ao qual falta ainda estabelecer um tratamento mais definido: em realidade, o fator central a diferenciar a programação ou o programa de outras produções que lhe fazem concorrência na faixa de atuação escolhida.

Explorar um segmento envolve as mais diversas possibilidades, limitadas somente pela criatividade dos que planejam um programa ou uma programação e pela possibilidade de sucesso dessas formas de pensar o público. A título de didatismo e dentro do escopo deste ensaio, listo a seguir os segmentos que creio ser fácil identificar nos principais mercados do Brasil:

(1) "Jornalístico": explorado pelas emissoras que se dedicam a uma programação em que predomina o jornalismo, podendo este incluir a cobertura esportiva em si, com a transmissão de competições ou com apenas o noticiário desse setor da atividade humana. Há, na exploração mínima desse segmento, a presença de âncoras, noticiando os principais fatos do momento e as mais significativas opiniões das fontes, além de explicarem estas últimas e se posicionarem a respeito delas. Na forma mais próxima da ideal, engloba os mais variados tipos de programa jornalístico; a presença de uma equipe estruturada de profissionais, com destaque para a reportagem; e a cobertura intensiva de acontecimentos culturais, econômicos, políticos e sociais, não raro do seu palco de ação, sem descuidar dos grandes eventos esportivos.

(2) "Popular": por vezes com práticas próximas do populismo - o comunicador que se coloca como um representante do povo ou uma espécie de defensor de suas causas -, apresenta programação baseada na simulação de uma conversa coloquial com o ouvinte, 
em hits musicais, nas informações relacionadas à vida pessoal de celebridades, na constante prestação de serviços e na exploração do noticiário policial. A respeito, vale a crítica de Eduardo Meditsch (2002, p. 59):

[...] nas rádios voltadas ao público de baixa renda, o acesso à inteligência é geralmente negado. Os grandes problemas da audiência não são enfrentados: ou são tangenciados pela dissimulação, ou sublimados pelo paternalismo dos comunicadores, que assim se tornam potenciais ocupantes de cargos políticos. A manipulação corre solta, até porque é de mau gosto, e quem poderia denunciá-la prefere não ouvir, está sintonizado em outra zona do dial. Sensacionalismo, violência, drama, berreiro, e a audiência se mantém altamente estimulada, desinformada e distraída.

Este tipo de rádio direciona-se a ouvintes, em geral, das classes C, D e E, com mais de 25 anos e escolaridade, frequentemente, inferior à conclusão do ensino fundamental, embora isso não possa ser tomado como uma regra absoluta.

(3) "Musical": ao contrário das duas formas de segmentação anteriores - baseadas na fala — , caracteriza-se pela transmissão de músicas com apresentação ou locução ao vivo ou gravada. É possível encontrar uma série de variantes, das quais destaco: (1) musical adulto, busca atingir uma audiência com idade superior a 25 anos. É o rádio da música contemporânea normalmente dirigida a ouvintes das classes A e B; (2) musical jovem, voltado, predominantemente, ao público dos 15 aos 25 anos, com uma programação baseada nos chamados sucessos do momento e conduzida por comunicadores que, com humor e muita agitação, procuram criar um forte elo de identificação com os ouvintes; (3) musical gospel, rádios de conteúdo religioso, geralmente ligadas a igrejas - católicas e, de modo mais frequente, evangélicas - , que transmitem canções de louvação aos princípios cristãos; (4) musical popular, pretende ter como público as classes $\mathrm{B}$ e $\mathrm{C}$, despontando canções de fácil apelo para o público, destacando-se gêneros como o pagode, o sertanejo e o romântico; e (5) musical jovem popular, caracterizado por mesclar o foco no 
público de 15 a 25 anos, com interesse em atingir os integrantes dessa faixa etária das classes B e C.

(4) "Religioso": com preponderância de um conteúdo falado, corporifica-se nas igrejas radiofônicas, ou seja, as emissoras postas exclusivamente a serviço de correntes religiosas e que transmitem cultos, curas pretensamente milagrosas, exorcismos e pregação baseada na Bíblia.

\section{O formato}

A ideia de formato radiofônico aparece aqui com o mesmo sentido associado a expressões como radio format, program format ou station format no mercado estadunidense ${ }^{5}$. A respeito, define Laurie Thomas

5. Tanto lá quanto cá existe ainda a expressão format clock ou formato

horário, padrão que baseia a marcação do tempo destinado aos conteúdos jornalísticos, de serviço,

de entretenimento, musicais e educativos em relação às parcelas ocupadas pelo intervalo comercial.

Em geral, no Brasil, as emissoras adotam, nesse sentido, três formatos, tendo por referência a hora cheia e podendo mesmo, ao longo do dia, alternar um e outro, conforme as necessidades do material veiculado e mesmo da faixa horária: quatro blocos de 12 a 13 minutos, três de 17 a 18 minutos ou dois de 27 a 28 minutos. Os espaços comerciais variam de dois a três minutos. Lee (2004, p. 612): "uma concepção global de programação de uma emissora ou programa específico. É, em essência, uma combinação de elementos [...] em uma sequência a qual irá atrair e prender o segmento de audiência que está sendo buscado". A adoção de uma radio formula, denominação inicial dessa estratégia de atuação, está, portanto, no cerne, lá, do processo de segmentação:

\begin{abstract}
O conceito, como ele surgiu no final dos anos 1940 e no início da década de 1950, envolveu mais a metodologia do que o conteúdo. As estações não pretendiam deixar as coisas ao acaso, nem condicionadas aos caprichos dos disk-jockeys,. Desenvolveram regras, dotando cada emissora de uma personalidade identificável pelos ouvintes. Essas regras podiam incluir rodar $\mathrm{X}$ número de canções por hora, identificar a rádio $X$ vezes e especificar quando inserir os comerciais. $\mathrm{O}$ que as fórmulas radiofônicas postularam é que o público gosta de coerência: não importa quem seja o DJ ou qual a hora do dia, a estação precisa ser reconhecida em relação à concorrência. Essa foi uma radical mudança de raciocínio (FORNATALE; MILLS, 1980, p. 13-14).
\end{abstract}

O formato constitui-se, assim, na maneira de abordar o segmento. Se este último é genérico, o formato, obrigatoriamente, apresenta características as mais específicas possíveis. Desse modo, dentro 
de um mesmo segmento, podem atuar emissoras com este ou aquele formato. Tal diferenciação conceitual ganha importância pela vigência de enorme, variada e crescente oferta de conteúdo comunicacional deste início de século 21. Há tal diversidade à disposição que, de um lado, uma emissora musical adulta com notícias atualizadas a cada 15 minutos e um bom conjunto de comentaristas talvez possa captar ouvintes antes exclusivos de uma estação dedicada 24 horas ao jornalismo. De outro, no segmento musical jovem, uma rádio pode optar pela repetição, de modo incessante, dos 40 principais hits - , enquanto outra decide pelo pop e pelo rock sem abdicar de alguns dos chamados sucessos do momento veiculados com menor frequência. No mesmo segmento, o de jornalismo, enquanto uma estação escolhe um formato como o news-talk (com noticiários, daí o news, e comentários, debates e entrevistas, daí o talk), outra assume o música-esporte-notícia, de conteúdo já explicado pela própria denominação do formato. E ambas talvez disputem público e rol de anunciantes semelhantes.

Resumindo o que até aqui foi exposto, a meu ver, em uma emissora de rádio, o processo de formatação engloba simultaneamente: (1) a demarcação da sua linha de programação, uma ideia geral dos padrões de conteúdo e de forma em relação ao conjunto de mensagens que se prevê que sejam transmitidas aos ouvintes; (2) a modelagem interna de cada programa; e (3) a adequação destes à grade horária, tanto do dia em si quanto da semana. Conforme David Hendy (2000, p. 95), em cujas observações baseio esses três itens, "um produto padronizado é provavelmente o melhor meio de obter, com previsibilidade, uma audiência determinada”. Atingir um segmento com um programa ou com uma programação representa, desse modo, a orientação do produto final por um formato determinado. Obviamente, deve-se pensar esse planejamento como um processo dinâmico, buscando ultrapassar os limites de uma reflexão mais mecanicista a considerar o público como um dado apenas numérico. Formatam-se a programação, que é o conjunto, e o conteúdo específico, este usualmente agrupado em programas.

Neste último caso, como observa David Hendy (2000, p. 95), significa determinar a estrutura e o estilo do programa: "seus 
conteúdos, estabelecidos com precisão, vão variar de uma edição para a próxima, mas a estrutura e o estilo serão sempre essencialmente os mesmos, no mínimo até que uma necessidade de modernização seja sentida e realizada em uma nova formatação". O professor da Universidade de Westminster destaca as semelhanças desse processo com o que ocorre em meios impressos e audiovisuais:

\footnotetext{
Isto proporciona ao ouvinte uma identificação perceptível do programa, porque torna cada edição isolada suficientemente familiar e oferece aos produtores um quadro seguro com o qual eles podem habitualmente trabalhar. Em certo sentido, não é diferente do planejamento visual que caracteriza cada jornal ou da cenografia de um programa de televisão. No entanto, enquanto tais formatos são reconhecidos de modo instantâneo, nós sabemos que a estrutura de um programa de rádio é invisível e apenas parcialmente revelada em uma primeira audição, talvez pela voz do seu apresentador e pelo estilo empregado por ele (linguagem, ritmo, grau de formalidade). Uma ideia completa só se revela gradualmente, em tempo real e ao longo da irradiação. Portanto, o formato de um programa - embora claramente relacionado com o som da transmissão a cada dado instante dela (o tom adotado pelo apresentador, seu ritmo de fala, a forma dos comerciais e assim por diante) - atende, acima de tudo, à sua ideia geral, uma vez que vai se revelando ao longo do tempo (HENDY, 2000, p. 95).
}

Dessa maneira, de um dia para o outro, a identidade de um programa vai se fixando na memória do ouvinte pela repetição da escuta e pela manutenção de determinadas características, do estilo do comunicador ao microfone à veiculação de mensagens de tipos similares em momentos mais ou menos semelhantes. A formatação cria limites e possibilidades ao estabelecer uma estrutura relativamente previsível sobre a qual pode - e deve -, no entanto, atuar a criatividade dos envolvidos no processo de produção.

Em termos de formatação de programação, existem terminologias empregadas no Brasil que não correspondem exatamente aos seus congêneres dos Estados Unidos, espécie de mercado-referência 
para o rádio comercial brasileiro. Isto se deve, de um lado, não só às adaptações aqui realizadas mas também a certo desconhecimento de alguns radiodifusores e, de outro, ao fato de a denominação de um formato indicar sempre uma ideia média a seu respeito, já que há uma imensa diversidade de possíveis combinações. Mesmo lá, como observa Steve Warren (2005, p. 42), identificar um formato por uma denominação - e, por extensão, demonstrar a que tipo de rádio a emissora dedica-se - é algo de precisão relativa. A variedade de combinações torna diferentes mesmo estações, por exemplo, que se autodenominam all-news. Dessa maneira, é usual deixar apenas implícito o formato e explicitar, sim, a identidade, resumindo-a a palavras-chave ou a slogans. Ciente disso, a tipologia que apresento a seguir constitui-se em uma listagem de formatos tomados em seus aspectos genéricos, procurando descrever como eles foram adaptados ao mercado brasileiro:

(1) "All-news, all-talk, talk-news e news plus": tais formatos, baseados de modo exclusivo em notícias - all-news preponderantemente na conversa - all-talk - ou derivados destes - talk-news e news plus -, possuem correspondentes no Brasil nos segmentos jornalístico e popular. Cabe observar que, em sua origem, o all-news apresentava uma sequência contínua de irradiação de notícias na forma de textos e reportagens, repetidas e atualizadas em períodos de tempo variando de 7 a 30 minutos. Já o all-talk, também conhecido como talk radio, envolvia programas com participação do ouvinte, que era instado a opinar a respeito de assuntos de atualidade.

Aqui, as emissoras dedicadas 24 horas por dia à notícia, mesmo que se assumindo como all-news ou apenas news, em realidade, desenvolveram um formato intermediário mais próximo do talknews. Ao optarem pelo jornalismo em tempo integral, rádios como a Gaúcha, do Grupo RBS, de Porto Alegre, já o fazem assumindose dentro de um híbrido, com entrevistas, noticiário puro e reportagens. Outras - é o caso da Central Brasileira de Notícias, das Organizações Globo, do Rio de Janeiro — surgiram definindose como all-news, mas com doses consideráveis de conteúdos que, na origem do formato, seriam considerados mais como próprios 
do talk. A ideia de repetição aparece com força na BandNews, do Grupo Bandeirantes de Comunicação, de São Paulo, projeto mais próximo do all-news estadunidense, que irradia blocos de 20 minutos com espaços padronizados com noticiário, prestação de serviços e comentários. Mesmo nela, há espaço para o talk, uma característica histórica do radiojornalismo brasileiro.

No caso do rádio popular de forte ligação com as parcelas mais pobres da sociedade, as emissoras dos principais centros, alheias ao que ocorre no rádio de outros países, desenvolveram programações centradas na figura do comunicador-amigo, que tanto conversa do estúdio por telefone com o ouvinte como faz entrevistas, interage com comentaristas e repórteres e/ou coordena mesas-redondas. Levando ao ouvinte uma combinação de entretenimento, notícias e prestação de serviços, transita, não raro, de uma espécie de autoajuda radiofônica ao assistencialismo, com doses de populismo e sensacionalismo. É um tipo de rádio mais próximo do all-talk das emissoras dos Estados Unidos. Entre as variações existentes por lá e baseadas no all-news e no all-talk, Michael C. Keith (2010, p. 82) cita o news plus, formato muito semelhante ao desenvolvido no Brasil e conhecido como música-esporte-notícia: "Mesmo que enfatize a notícia, alguns períodos são preenchidos por música [...]. Emissoras do tipo news plus também possuem uma grade fortemente voltada aos eventos esportivos".

(2) "Adulto contemporâneo": nos Estados Unidos, o formato adult contemporary e os seus derivados voltam-se à faixa etária dos 25 aos 49 anos e posicionada socioeconomicamente nas classes A e B. A programação musical compõe-se basicamente de standards de pop music e alguns hits; nunca rock mais pesado. De fato, tirando canções consagradas - em geral, baladas - , quase nada que possa ser identificado como rock é transmitido. No caso brasileiro, a isso, acrescentam-se, por vezes, MPB e alguns clássicos do sambacanção. Fique claro, portanto: o adulto contemporâneo caracterizase por uma sonoridade menos agitada, da qual não fazem parte nem riffs de guitarra nem batucadas carnavalescas.

(3) "Country, jazz, pop, rock e outros formatos por gênero musical": essa formatação é prática comum tanto nos Estados 
Unidos - country, jazz, rock etc. - quanto no Brasil. Aqui, como lá, há uma variedade considerável: das presentes em vários pontos do país - funk, pagode, sertanejo, techno... - às de cunho mais regional - axé, forró, gauchesca... - , algumas destas últimas, por vezes, ocupando mesmo espaços fora de suas regiões de origem. Em menor proporção, umas poucas emissoras dedicam-se ao rock, do mais clássico às suas diversas variações.

(4) "Beautiful music, easy music ou golden music": é o rádio no qual predominam orquestrações ou seja, versões instrumentais, como definem Peter Fornatale e Joshua Mills (1980, p. 77-78): “Seu conteúdo inclui arranjos exuberantes, altamente orquestrados e arranjos adocicados de antigos clássicos, sucessos populares, melodias de espetáculos e obras semiclássicas”. Eventualmente, envolve vocalizações em que a base seguem sendo o instrumental e o coro, de fato, não usando palavras - apenas fazendo o acompanhamento com articulações de sons. No Brasil, constituiu-se na opção inicial das emissoras pioneiras em frequência modulada. Volta-se a um público mais velho do que o adulto contemporâneo.

(5) "Contemporary hit radio (CHR) ou Top 40": formato conhecido até alguns anos como Top 40, por se basear na repetição dos 40 principais sucessos musicais, priorizando ou não, conforme o momento, os colocados nas primeiras posições. Foi pensado para o público jovem e marcou a programação das emissoras desse segmento musical até a internet popularizar o download de canções. O formato contemporary hit radio, ou CHR, representa uma redefinição do Top 40 original, mantendo a ideia de alta estimulação associada ao desempenho do comunicador, uma rádio agitada e inquieta, sem espaço para nada além da fala do DJ e das músicas, que, no seu conjunto, garantem um estado de permanente agitação por parte do ouvinte jovem. Como destaca Michael C. Keith (2010, p. 77), o silêncio, identificado como "dead air", é o inimigo.

(6) "Clássico": são raras as emissoras que se dedicam à veiculação de música erudita no Brasil. Por ser considerado de difícil aplicação comercial é, em geral, no país, um formato associado ao rádio educativo. Programações desse tipo privilegiam movimentos 
específicos - partes - das obras e reservam outros horários à execução de peças completas.

(7) "Flashback": usualmente conhecido por essa denominação no Brasil, esse formato confunde-se um pouco com o que, nos Estados Unidos, leva o nome de classic - emissoras que, por exemplo, tocam os chamados clássicos do rock'n'roll; "nostalgia", voltado à veiculação das big bands e dos grandes intérpretes dos anos 1940 e 1950; e oldies, concentrado nos grandes sucessos dos anos 1950 e 1960, incluindo entre eles o rock mais consagrado. Aqui, flashback identifica um leque considerável de programações. Pode se referir a sucessos - antigos hits e, com certeza, muitos standards - dos anos 1980 e 1990; das duas décadas anteriores, com doses significativas de música jovem, rock ou não; da Velha Guarda, do chorinho e do samba; da MPB em geral...

(8) "Eclético": típico das emissoras brasileiras de centros urbanos de menor porte que optam por segmentar suas programações por horário. De início, era adotado exclusivamente por estações em ondas médias. Com a outorga de canais em frequência modulada para pequenas localidades sem outras emissoras, começou a ser usado também em rádios dessa faixa de transmissão. Constitui-se em um conjunto de programas buscando agradar a vários tipos de ouvinte. Por exemplo, entre as $6 \mathrm{~h}$ e as $8 \mathrm{~h}$, ocorrem emissões para um público bem genérico, com informações para quem está acordando, entremeadas, não raro, por músicas. Na sequência, entram programas jornalísticos abordando os principais fatos do município e da região, voltados aos formadores locais de opinião. É o espaço em que o prefeito, seus secretários, os vereadores e outras personalidades do município concedem entrevistas ou participam de mesasredondas. Parte da manhã ou da tarde, no entanto, é preenchida por comunicadores populares, com a emissora procurando atingir, desse modo, as classes $\mathrm{C}$ e D. Além disso, a programação pode incluir música, transmissões esportivas locais e, mesmo, espaços terceirizados. Assemelha-se ao estadunidense full service - também conhecido como variety, general appeal ou diversified - , oferecendo aos ouvintes de cidades pequenas, do 
mesmo modo que aqui, música, notícias e esportes. Lá, também, verifica-se uma menor disparidade entre o público das diversas faixas de programação.

(9) "Religioso": no Brasil, constitui-se em uma espécie de igreja radiofônica, associado, de modo predominante, a vertentes religiosas de cunho evangélico e a algumas facções carismáticas do catolicismo romano. Inclui, basicamente, pregação e as chamadas curas milagrosas, embora abra espaços para programas nos quais, por óbvio, dependendo do caso, pastores ou padres conversam com ouvintes, dando uma espécie de aconselhamento espiritual. Há dose significativa também de incitação a doações para as respectivas igrejas e de publicidade de produtos e serviços a elas relacionados. Seu correspondente estadunidense, sem diferir muito na finalidade, apresenta parcela maior de programas de opinião, em geral associados ao conservadorismo político e social.

(10) "Serviço": o que, no Brasil, se conhece como uma rádio de serviços enquadra-se no formato all-talk. Aqui, trata-se, de modo mais específico, de uma emissora jornalística voltada, integralmente, ao gênero utilitário, possuindo, na definição de Tyciane Cronemberger Viana Vaz (2010, p. 138), "um papel orientador, que busca ajudar o cidadão em suas escolhas e atividades do cotidiano”. Portanto, além das informações sobre aeroportos, hora, mercado financeiro, pagamento de impostos, previsão do tempo, recebimento de aposentadorias e pensões, roteiro cultural, temperatura, trânsito etc., há uma constante intermediação da rádio e de seus comunicadores na resolução de problemas da população. Por telefone, no estúdio, junto a repórteres ou por qualquer outro meio disponível, o ouvinte narra determinada situação e, constatada a veracidade do relato, a emissora entra em contato com os órgãos públicos responsáveis, que, assim, são instados a se manifestar a respeito.

\section{A programação}

Conjunto organizado dos conteúdos veiculados por uma emissora de rádio, jornalísticos, de entretenimento, de serviços, publicitários e/ou musicais, produzidos conforme o formato 
adotado pela emissora. Tem, em geral, embora não de modo obrigatório, o programa como unidade básica. Algumas estações, no entanto, por necessidades econômico-financeiras e mesmo de mercado, transmitem conteúdos sem que eles apareçam divididos em programas. É o caso das que adotam formatos musicais e que se limitam a blocos de canções e, quando há, à identificação delas por um locutor.

No Brasil, como observado anteriormente (FERRARETTO, 2007, p. 59-61), podem ser encontrados três tipos básicos de programação radiofônica: (1) "linear": a mais frequente nas grandes emissoras do país, com conteúdos mais homogêneos, que seguem um formato claro e definido, no qual as partes podem se diferenciar um pouco entre si, havendo, no entanto, uma harmonia entre elas; (2) "em mosaico": usual em pequenas estações de formato eclético e localizadas em cidades de menor porte, englobando um conjunto de conteúdos extremamente variados e diferenciados, na prática, segmentados por horários; e (3) "em fluxo": comum em emissoras de formato semelhante ao all-news dos Estados Unidos ou nas do segmento musical.

A programação em fluxo caracteriza-se por uma forma de fazer rádio estruturada em uma emissão constante, em que se toma toda a programação como um grande programa, dividido em faixas bem definidas. As mudanças de uma para outra são calcadas na troca do âncora ou do comunicador do horário. Desde o início do século 21, algumas rádios voltadas ao jornalismo têm se aproximado disso. É o caso, por exemplo, das rádios BandNews e Bradesco Esportes, ambas ligadas ao Grupo Bandeirantes, de São Paulo.

\section{O conteúdo em si}

Usualmente, o programa é a forma mais comum de divisão do conteúdo da programação. Gravado, ao vivo, ou utilizando de forma combinada essas duas possibilidades de transmissão, ele se constitui em um todo coeso e independente dentro do conjunto das emissões. Alvaro Bufarah Júnior (2010, p. 963) define programa como: "Módulo ou unidade básica da programação radiofônica, 
6. Desde a década de 1990, no entanto, seu uso tem diminuído, optando-se pela apresentação da informação pelo próprio comunicador do horário. Edições extras ficaram, assim, restritas a interrupções ao vivo, em caso de fato de importância extrema, por jornalistas de plantão, em meio à programação gravada. embora esta possa conter conteúdos não organizados desta forma (por exemplo, no caso de uma emissão musical contínua)". Nessa linha de raciocínio, conteúdos como comentários, entrevistas, quadros específicos e reportagens são considerados como parte integrante dos programas ou - quando tomados isoladamente, em função das necessidades comerciais das estações de rádio - como programetes, emissões em geral não superiores a cinco minutos de duração, mas de características próprias.

Ampliando o já apresentado anteriormente (2007, p. 54-59) e observando que eles têm sua origem no rádio dos Estados Unidos, creio ser possível classificar os programas de rádio em:

(1) "Noticiários": aquele em que predomina a difusão de notícias na forma de textos e/ou reportagens. subdividindo-se em: (a) síntese noticiosa, que, tendo por modelo o Repórter Esso, de origem estadunidense, pretende, como diz o nome, sintetizar os principais fatos ocorridos desde a sua última transmissão, constituindo-se num informativo no qual o texto curto e direto predomina em uma edição que privilegia a similaridade de assuntos; (b) radiojornal, versão radiofônica dos periódicos impressos, reunindo várias formas jornalísticas (boletins, comentários, editoriais, seções fixas - meteorologia, trânsito, mercado financeiro... - e mesmo entrevistas); (c) edição extra ${ }^{6}$, mini-informativo marcado por uma trilha forte, irrompendo em meio à programação e noticiando um acontecimento cuja divulgação não pode esperar o próximo noticiário da emissora; (d) toque informativo, espaço típico das emissoras musicais, que inclui uma ou duas notícias e é transmitido, em geral, nas horas cheias, permitindo, com frequência, que o comunicador não se atenha somente ao texto, mas improvise em cima dele; e (e) informativo especializado, que pode adotar a forma de uma síntese noticiosa ou de um radiojornal, mas se diferencia deles pela especificidade dos assuntos tratados, concentrando-se em uma área de cobertura bem determinada - por exemplo, o noticiário esportivo.

(2) "Programa de entrevista": representa parcela significativa da programação das emissoras dedicadas ao jornalismo. Nele, é fundamental a figura do apresentador que conduz as entrevistas, 
chama repórteres e, quando necessário, emite opiniões. No entanto, a interpelação de protagonistas dos fatos ou de analistas ocupa a maior parte da emissão.

(3) "Programa de opinião": o lado opinativo do apresentador predomina, tornando-se a atração principal, secundada por comentaristas e mesmo repórteres. Constitui-se por si só em uma visão quase pessoal da realidade, cujo sucesso está vinculado às polêmicas geradas pelo condutor do programa. É mais comum no rádio dos Estados Unidos, aparecendo na forma dos chamados talk-shows.

(4) "Programa de participação do ouvinte": baseia-se na opinião dos ouvintes instados por um apresentador a debaterem determinados assuntos, dos grandes temas do noticiário a questões comportamentais cotidianas.

(5) "Mesa-redonda": a opinião de convidados ou de participantes (fixos ou não) constitui a base da mesa-redonda, tradicional tipo de programa radiofônico que procura aprofundar temas de atualidade. Pode ser de dois tipos: (a) painel, quando cada integrante da mesa expõe suas opiniões, que vão se complementando, com o objetivo principal de fornecer um quadro completo a respeito do assunto enfocado; e (b) debate, quando a produção do programa busca pessoas com pontos de vista conflitantes, colocando-as frente a frente e objetivando proporcionar um confronto de opiniões.

(6) "Jornada esportiva": irradiação baseada na descrição contínua e pormenorizada de um acontecimento esportivo. No caso brasileiro, a mais comum e frequente é a transmissão de jogos de futebol.

(7) "Documentário": pouco utilizado tanto cá como lá - é mais comum em emissoras da rede pública estadunidense - , aborda um determinado tema em profundidade. Baseia-se em uma pesquisa de dados e de arquivos sonoros, reconstituindo ou analisando um fato importante. Inclui, ainda, recursos de sonoplastia, envolvendo montagens e a elaboração de um roteiro prévio.

(8) "Radiorrevista ou programa de variedades": reúne aspectos informativos e de entretenimento. Nas emissoras dedicadas ao 
jornalismo, pode aparecer na forma de espaços voltados à cultura e ao lazer, intercalados, algumas vezes, com orientações nas áreas de medicina ou de direito. Nas voltadas ao segmento popular, engloba da prestação de serviços à execução de músicas, passando por temas diversificados, como notícias policiais, horóscopo ou entrevistas com atores e atrizes de telenovelas.

(9) "Programa humorístico": teve sua era de ouro nas décadas de 1930, 1940 e 1950, quando, em torno de um roteiro marcado por um cuidadoso trabalho de sonoplastia, os comediantes do rádio arrancavam gargalhadas das plateias nos auditórios das emissoras e nas casas dos ouvintes espalhados pelo país. Nas últimas duas décadas - em especial, por influência do sucesso obtido pelo programa Pânico, da Jovem Pan FM, de São Paulo -, o humor retornou no rádio musical jovem brasileiro. Na maioria desses casos, mais do que a piada ou o sketch preparado com antecedência, predomina o improviso calcado no deboche e no raciocínio rápido.

(10) "Programa musical”: pelo lado do entretenimento, a música preencheu o espaço deixado na programação pelos programas de auditório, humorísticos e dramatizações, que saíram gradativamente de cena depois de 1950, com o surgimento da televisão. Esse tipo de conteúdo fez a base das emissoras em frequência modulada até a virada para o século 21, quando programações calcadas na fala também passaram a ganhar espaço nessa faixa de irradiação.

Historicamente, podem ser citados ainda as dramatizações e os programas de auditório, em desuso tanto lá quanto cá desde a década de 1960.

\section{Considerações finais}

Com a certeza de não ter esgotado o tema, que, como já observado, creio carecer de uma pesquisa de campo mais apurada, procurei neste ensaio apresentar um esboço de marco para analisar de modo mais abrangente o conteúdo radiofônico em seus elementos e em sua complexidade. Parti, assim, de modelos estadunidenses. De fato, preocupa-me a constatação de que, como pesquisadores, tenhamos deixado de lado o estudo das metodologias de planejamento e de 
gestão de conteúdo radiofônico. Pela observação assistemática e, portanto, sem a cientificidade necessária - e por eventuais contatos com profissionais de mercado, gestores de emissoras e mesmo seus proprietários, acredito haver no país certo grau de confusão teórica entre o que seja segmento e o que seja formato. Tenho convicção de que o primeiro chega a ser definido, mas o segundo, por carência metodológica, é pouco explorado cá no Brasil, resultando, concretamente, em emissoras sem identidade clara perante seu público.

Este ensaio, portanto, constitui-se em uma tentativa de iniciar uma abordagem mais ampla, que é necessária, em especial, quando o governo federal e a indústria de radiodifusão sonora preocupamse tanto com a passagem do analógico para o digital. É, sem dúvida, um tema premente. No entanto, tecnologia constitui-se em suporte, algo que perde função sem conteúdo e sem pessoal habilitado para refletir sobre o que vai ser irradiado e planejá-lo. Os próprios cursos universitários da área de comunicação social não têm dado resposta a isso, concentrando-se quando muito no ensino das rotinas de produção, ou seja, do já estabelecido. Não é um passo tão difícil a ser dado, já que existe, dentro das mesmas instituições, uma pesquisa consolidada em relação ao rádio e às demais mídias sonoras.

Ressalto que o aqui exposto não pode ser visto, dessa maneira, como algo acabado e definitivo. Trata-se de um esboço de modelo, incitando à reflexão. Deve ser encarado, ainda, como um processo contínuo de reavaliação de uma emissora e do que ela oferece aos ouvintes; quatro níveis estratégicos - segmento, formato, programação e conteúdo em si - em constante interação e inter-referência, atuando conjuntamente na construção da identidade da rádio. 


\section{Referências}

BARBOSA FILHO, A. Gêneros radiofônicos: os formatos e os programas em áudio. São Paulo: Paulinas, 2003.

BUFARAH JÚNIOR, A. "Programa radiofônico". In: ENCICLOPÉDIA INTERCOM DE COMUNICAÇÃO. São Paulo: Sociedade Brasileira de Estudos Interdisciplinares da Comunicação, 2010. v. 1. CD-ROM.

DICIONÁRIO ELETRÔNICO HOUAISS DA LÍNGUA PORTUGUESA. Rio de Janeiro: Objetiva, 2007. CD-ROM.

FERRARETTO, L. A. “Aqui, o rádio de lá: uma análise histórica das influências estrangeiras nas emissoras brasileiras". Animus, Santa Maria, v. 18, n. 2, jul.-dez. 2010.

Rádio: o veículo, a história e a técnica. 3.ed. Porto Alegre: Doravante, 2007.

. "Uma proposta de periodização para a história do rádio no Brasil”. Revista de Economia Política das Tecnologias da Informação e Comunicação, Aracaju, v. 14, n. 2, maio-ago. 2012.

FERREIRA, A. B. de H. Novo dicionário da língua portuguesa. Rio de Janeiro: Nova Fronteira, 1983.

FORNATALE, P.; MILLS, J. E. Radio in the television age. New York: The Overlook Press. 1980.

HAUSMAN, C.; MESSERE, F.; O’DONNELL, L.; BENOIT, P. Rádio: produção, programação e performance. São Paulo: Cengage Learning, 2010.

HENDY, D. Radio in the global age. Cambridge: Polity Press, 2000.

KEITH, M. C. The radio station; broadcast, satellite and internet. Burlington (Massachusetts): Focal Press, 2010

LEE, L. T. "Formats”. In: STERLING, C. H. (Ed.). The Museum of Broadcast Communications encyclopedia of radio. New York: Taylor and Francis Group, 2004. v. 2.

LUCHT, J. M. P. "Gêneros no radiojornalismo". In: MELO, J. M. de; ASSIS, F. de (Org.). Gêneros jornalísticos no Brasil. São Bernardo do Campo: Universidade Metodista de São Paulo, 2010. 
MEDITSCH, E. "Fatiando o público: o rádio na vanguarda da segmentação da audiência". Verso \& Reverso, São Leopoldo, ano 16, n. 35, jul.-dez. 2002.

RICHERS, R. "Objetivos e méritos da segmentação no Brasil". Mercado Global, Rio de Janeiro, ano 16, n. 79, jun./jul. 1989. "Segmentação de mercado: uma visão de conjunto". In: RICHERS, R.; LIMA, C. P. (Org.). Segmentação: opções estratégicas para o mercado brasileiro. São Paulo: Nobel, 1991.

SAMPAIO, M. F. História do rádio e da televisão no Brasil e no mundo (memórias de um pioneiro). Campos dos Goytacazes: Fundação Estadual Norte Fluminense, 2004.

STERLING, C. H. (Ed.). The Museum of Broadcast Communications encyclopedia of radio. New York: Taylor and Francis Group, 2004. 3 v.

TECNOPOP. Rádio Globo: o projeto de branding (parte 1). Rio de Janeiro, 29 abr. 2009(a). Disponível em: <http://blog.tecnopop. com.br/artigo-blog/radio-globo-o-projeto-de-branding-parte-l/>. Acesso em: 10 out. 2010.

Rádio Globo: o projeto de branding (parte 2). Rio de Janeiro, 5 maio 2009(b). Disponível em: <http://blog.tecnopop. com.br/artigo-blog/radio-globo-o-projeto-de-branding-parte-2/>. Acesso em: 10 out. 2010.

Rádio Globo: o projeto de branding (parte 3). Rio de Janeiro, 12 maio 2009@. Disponível em: <http://blog.tecnopop. com.br/artigo-blog/radio-globo-o-projeto-de-branding-parte-3/>. Acesso em: 10 out. 2010.

VAZ, T. C. V. "Gênero utilitário". In: MELO, J. M. de; ASSIS, F. de (Org.). Gêneros jornalísticos no Brasil. São Bernardo do Campo: Universidade Metodista de São Paulo, 2010.

WARREN, D. Radio: the book. For creative. professional programming. Burlington (Massachusetts): Focal Press, 2005.

ZOZZOLI, J. J. “Marca”. In: ENCICLOPÉDIA INTERCOM DE COMUNICAÇÃO. São Paulo: Sociedade Brasileira de Estudos Interdisciplinares da Comunicação, 2010. v. 1. CD-ROM. 